\title{
BIMBINGAN BELAJAR DI CURUG TANGERANG
}

\author{
Wiyun Philipus Tangkin ${ }^{1}$, Wiputra Cendana ${ }^{2}$ \\ ${ }^{1}$ Universitas Pelita Harapan \\ ${ }^{2}$ Universitas Pelita Harapan
}

wiyun.tangkin@uph.edu, wiputra.cendana@uph.edu

\begin{abstract}
Abstrak
Tingkat kemampuan ekonomi yang lemah (kaum marginal) bukan saja memberikan kesempatan yang kurang, dalam memperoleh pendidikan berkualitas di sekolah namun juga kesempatan di luar sekolah. Orang tua tidak mampu memberikan les tambahan atau bimbingan belajar sehingga memperparah keterpurukan dalam memahami materi pembelajaran di sekolah. Akibatnya, anak tidak menyukai sekolah, maka dapat diprediksikan hasil belajar pun tidak maksimal. Berdasarkan dari kebutuhan tersebut maka UPH-Teachers College mengadakan Bimbingan Belajar di Perum Griya Karawaci, Curug-Tangerang. Bimbingan Belajar ini bertujuan untuk memberikan pembekalan berupa pembelajaran tambahan serta pendampingan anak belajar dari tingkat TK, SD, SMP, dan SMA. Materi yang diajarkan disesuaikan dengan materi sekolah masing-masing siswa. Metode belajar bermain akan diterapakan untuk siswa TK-SD kelas 3 sedangkan untuk SD kelas 4 hingga seterusnya akan disesuaikan dengan materi yang diajarkan. Kegiatan Bimbingan Belajar ini dilakukan 2 kali pertemuan per minggu, dan yang mengajar adalah mahasiswa Fakultas Ilmu Pendidikan-Teachers College yang sudah diseleksi sebelumnya. Adapun hasil evaluasi setelah berjalan sejak awal hingga pertengahan tahun 2019 yaitu kegiatan ini membantu siswa dalam meningkatkan kemampuan membaca, menulis, dan berhitung bagi siswa TK-SD dan meningkatkan kemampuan Matematika untuk siswa SMP-SMA.
\end{abstract}

Kata kunci: bimbingan belajar, marginal, siswa

\section{PENDAHULUAN}

Undang-undang Pendidikan Nasional No. 20 tahun 2003 menyebutkan bahwa, pendidikan merupakan usaha sadar dan terencana untuk mewujudkan suasana belajar dan proses pembelajaran agar peserta didik secara aktif mengembangkan potensi dirinya. Salah satu konsep agar siswa mampu mengembangkan potensi dirinya adalah dengan cara belajar. Belajar merupakan kebutuhan yang harus dipenuhi oleh siswa, karena dengan belajarlah siswa dapat memperoleh ilmu pengetahuan yang luas dan mampu mengaplikasikan dalam kehidupannya sehari-hari. Kondisi siswa di pemukiman perumahan Griya Karawaci kurang menunjukkan antusias belajar. Hal ini juga terlihat dari hasil belajar mereka. Berdasarkan permasalah tersebut maka dilaksanakanlah PkM di tempat itu.
PkM ini adalah bentuk kerjasama antara Gereja Baptis Indonesia dengan UPH-Teachers College Program Studi Pendidikan Guru Sekolah Dasar (PGSD) yang telah berlangsung sejak Agustus 2018. Bentuk kegiatan ini berupa kegiatan bimbingan belajar dengan nama Bimbingan Belajar Eagle Nest, dimana mahasiswa UPH-Teachers College yang bertugas sebagai pengajar (tutor) dan peserta didiknya adalah siswa-siswa TK-SMA yang telah dikumpulkan oleh Gereja Baptis Indonesia di daerah Perumahan Griya Karawaci, Curug (tinggal di sekitar perumahan tersebut).

Kegiatan ini berawal dari permohonan pihak Gereja Baptis Indonesia kepada UPH-Teachers College, untuk dapat mewujudkan kerinduan dalam mengambil bagian pelayanan masyarakat kaum marginal, di daerah sekitar gereja terutama di bidang pendidikan. Keprihatinan tercetus saat mendengar

$$
\text { Pendidikan }
$$


sharing dari anggota Gereja yang tinggal di daerah setempat yang prihatin terhadap masyarakat sekitar, dimana anak-anak yang berperan sebagai siswa mengalami kesulitan belajar. Hal tersebut disebabkan oleh beberapa faktor dan salah satu diantaranya adalah status ekonomi keluarga yang relatif rendah di daerah tersebut.

Tingkat kemampuan ekonomi yang lemah bukan saja memberikan kesempatan yang kurang dalam memperoleh pendidikan berkualitas di sekolah namun juga kesempatan di luar sekolah. Orang tua tidak mampu memberikan les tambahan atau bimbingan belajar sehingga memperparah keterpurukan dalam memahami materi pembelajaran di sekolah. Slameto, (2010), mengatakan bahwa keadaan ekonomi keluarga erat hubungannya dengan hasil belajar siswa. Hal ini senada dengan argumen Hill, (1999), bahwa kelas sosial ekonomi berpengaruh terhadap pendidikan yang dialami oleh golongan tertentu, termasuk pengalaman pembelajaran dan ruang lingkup materi yang diperoleh terlepas dari standar pendidikan nasional yang dikeluarkan oleh pemerintah. Akibatnya, mereka tidak menyukai kegiatan belajar di sekolah. Sudah tentu, jika tidak menyukai sekolah, maka dapat diprediksikan hasil belajar pun tidak maksimal. Hal yang sama juga dikatakan oleh Zaini, dkk. (2015), bahwa keberhasilan belajar seorang siswa dipengaruhi oleh berbagai faktor, baik faktor yang berasal dari dalam diri (internal) maupun dari luar (eksternal). Faktor eksternal biasanya dipengaruhi oleh keadaan perekonomian keluarga. Dampak dari rendahnya kasadaran siswa terhadap tanggung jawabnya untuk belajar, maka akan sangat memengaruhi masa depannya, masa depan nantinya akan memengaruhi keadaan sosial sekitarnya, termasuk keluarganya. Jika hal ini terus-menerus berlangsung tanpa adanya solusi maka akan menjadi bom waktu dimana akan tercipta komunitas yang rendah tingkat sumber daya manusianya. Dampaknya bisa kemana-mana.

Penyebab lainnya juga adalah karena kurangnya pendampingan orang tua dalam kegiatan belajar anak selepas dari sekolah. Hal ini tidak terlepas dari keberadaan orang tua yang bekerja, atau yang tingkat pendidikan rendah sehingga tidak dapat mendampingi anak belajar di rumah. Materi pelajaran yang semakin sulit juga menjadi pengaruh orang tua sulit mendampingi anak. Hal ini selaras dengan yang dikatakan oleh Bakhtiyar, (2019), bahwa partisipasi orang tua dalam proses pendidikan masih tergolong rendah. Akibatnya proses belajar anak belum tergolong menyenangkan, sehingga anak belum dapat mengembangkan potensinya. Kendati di sekolah sudah ada guru sebagai pendamping dan pembimbing anak-anak belajar, namun bimbingan dan pendampingan belajar perlu dilanjutkan di rumah atau setelah jam sekolah. Pengkondisian belajar yang dilakukan secara berkesinambungan akan membantu siswa mengembangkan potensinya. Berdasarkan permasalahan tersebut maka dapat disimpulkan bahwa anak membutuhkan pendampingan atau bimbingan dalam belajar, terutama setelah jam sekolah. Belajar tidak seharusnya dibatasi oleh jam sekolah, tetapi proses belajar itu harusnya berlangsung secara terus menerus bahkan sepanjang hidup.

Menurut Qomaruddin, (2017), bimbingan adalah bantuan yang diberikan kepada seseorang agar mengembangkan potensi-potensi yang dimiliki di dalam dirinya sendiri dalam mengatasi persoalanpersoalan sehingga dapat menentukan sendiri jalan hidupnya secara bertanggungjawab tanpa harus bergantung dengan orang lain. Dengan kata lain bimbingan bertujuan untuk memandirikan orang yang dibimbing. Berarti akan ada masa dimana anak akan hidup mandiri tanpa bergantung dengan orang lain termasuk oleh orang tuanya. Oleh karena itu pentingnya membimbing anak agar mandiri, dan hal ini sebaiknya dilakukan dalam rentang usia 0-18 tahun.

Bimbingan belajar sebaiknya dilakukan terus menerus secara berkesinambungan agar prestasi belajar anak dapat optimal. Teori yang mendasari bimbingan belajar ini adalah teori yang diusung oleh Lev Vygotsky, yaitu Teori Konstruktivisme Sosial. Dalam teorinya, Vygotsky mengatakan bahwa di samping guru, teman sebaya juga berpengaruh penting pada perkembangan kognitif anak. Dalam hal ini Vygotsky menjelaskan bahwa satu anak bisa lebih efektif membimbing anak lainnya melewati ZPD (Zone of Proximal Development atau area dimana siswa tidak dapat mengembangkan kognitifnya tanpa bantuan dari orang lain), dengan menyediakan scaffolding (alat bantu untuk membimbing siswa belajar) yang sesuai. Bimbingan belajar dengan menyediakan tutor sebagai pendamping/ pembimbing merupakan salah

$$
\text { Pendidikan }
$$


satu cara untuk membantu siswa meningkatkan perkembangan kognitifnya. Berikut ini adalah gambar mengenai ZPD:

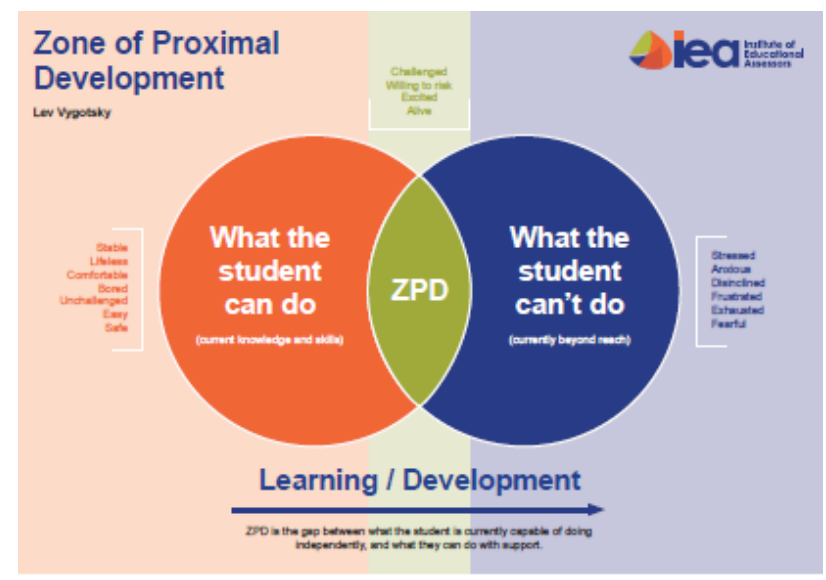

Gambar 1. Zone of Proximal Development

Pada gambar 1 (menggunakan pemisalan Diagram Venn) di atas, menjelaskan bahwa ada area dimana siswa bisa melakukan (warna oranye), area siswa tidak bisa (warna biru), dan area siswa membutuhkan bantuan orang lain untuk bisa (irisan berwarna hijau). Pada area irisan itulah siswa membutuhkan orang lain di luar dari dirinya untuk membantu mengembangkan potensinya berupa ranah kognitif, afektif, dan juga psikomotorik.

Dalam bimbingan belajar ini menggunakan istilah tutoring dimana tutor sebagai pembimbing yang akan mendampingi dan mengajar siswa. Santrock, (2007) dalam bukunya mengatakan bahwa tutoring pada dasarnya adalah pelatihan kognitif antara pakar dan pemula. Tutoring bisa terjadi antara orang dewasa dan anak-anak, atau anak yang lebih pandai dengan anak yang kurang pandai. Dengan kata lain tutoring adalah pendampingan belajar yang dilakukan oleh orang yang sudah lebih dulu tahu terhadap siswa yang belum tahu. Mengajari orang lain tentang sesuatu adalah cara terbaik untuk belajar. Prinsip inilah yang dialami oleh setiap guru. Ini sesuai dengan pepatah bahwa semakin digunakan semakin bertambah. Begitulah cara kerja ilmu, semakin dibagi maka sebenarnya semakin mahir dalam pengetahuan tersebut. Tuhan menciptakan cara kerja otak manusia sedemikian baik, dimana cara kerjanya, pengetahuan manusia tidak akan habis sekalipun dibagikan. Justru semakin dibagi maka semakin bertambah. Hal ini dapat terjadi karena proses pengulangan di dalam otak.

Proses pengulangan dalam belajar sesuai dengan teori Pemrosesan Informasi yang diusung oleh Robert Gagne (1985). Teori ini menjelaskan bahwa pembelajaran adalah hal yang sangat penting dalam perkembangan. Hal ini dapat dijelaskan melalui gambar Proses metacognition berikut ini:

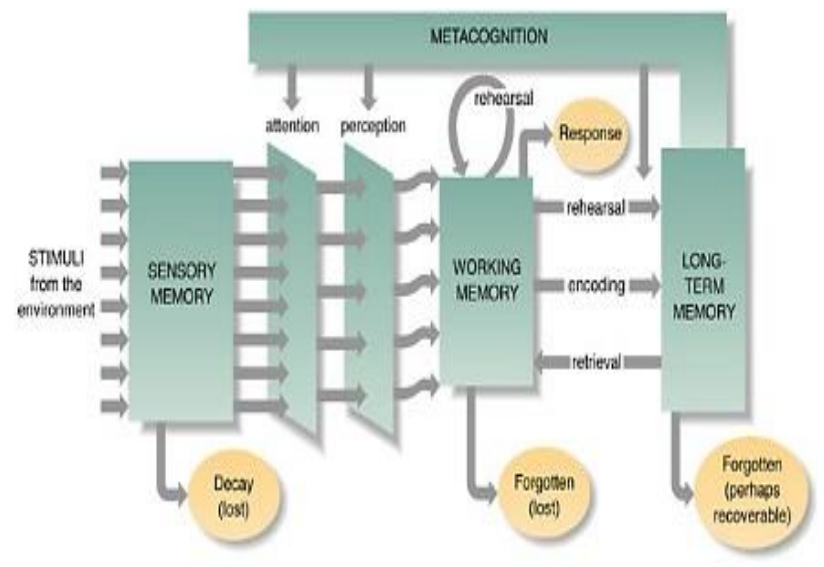

Gambar 2. Proses Metacognition

Proses metacognition pada gambar 2 menjelaskan mengenai alur informasi yang diterima oleh otak. Pada working memory terjadi beberapa proses yang dapat dilakukan agar informasi dapat tinggal lama di dalam long term memory. Beberapa proses dalam working memory tersebut yaitu proses rehearsal (pengulangan), encoding (pengkodean), dan retrieval (mengingat kembali). Jika informasi tidak melalui salah satu atau beberapa proses dalam working memory maka informasi hanya akan tinggal sebagai short term memory (ingatan jangka pendek/ tidak bertahan lama/ dilupakan). Semakin sering informasi diulang atau diingat maka akan sangat mudah informasi itu bertahan dalam dalam ingatan. Proses inilah yang sangat diharapkan dapat dialami oleh tutor sebagai mahasiswa calon guru.

Dengan kata lain, dampak dari bimbingan belajar dengan metode tutoring tidak hanya dirasakan oleh siswa tetapi juga oleh mahasiswa yang berperan sebagai pengajar/ pembimbing (tutor). Tutor mendapatkan manfaat juga karena dapat langsung mempraktekkan belajar mengajar, proses mengulang kembali materi pembelajaran yang sedang diajarkan dan sudah pernah didapatkan, mengenal karakteristik siswa melalui interaksi, dan

$$
\text { Pendidikan }
$$


lain sebagainya. Pengalaman ini tentunya menjadi bekal yang sangat bermanfaat bagi mahasiswa calon guru sebelum menjalani panggilan mereka nantinya saat menjadi guru.

Bimbingan belajar ini bersifat non formal. Proses belajar tidak seperti di sekolah. Siswa belajar dengan kondisi lebih santai, baju bebas santai, dapat berinteraksi dengan teman sebaya, menganggap tutor seperti kakak, metode pembelajarannya juga disesuaikan dengan jenjang pendidikan siswa. Ice breaking atau games merupakan bagian dari proses belajar pada bimbingan belajar ini, belajar sambil bermain, bercanda, termasuk bercerita. Hal ini membantu siswa lebih mudah untuk mengalami dan menikmati proses belajar karena tidak tertekan atau tegang.

Pembelajaran juga dibagi dalam kelompok. Pembagiannya disesuaikan dengan jenjang pendidikan siswa. Paling banyak per kelompok sekitar 4-5 siswa. Model pembelajaran secara berkelompok ini dikenal dengan model pembelajaran kooperatif. Menurut Slavin, dalam Nurdyansyah \& Fahyuni (2016), pembelajaran kooperatif menggalakkan siswa berinteraksi secara aktif dan positif dalam kelompok, memperbolehkan terjadinya pertukaran ide, dalam suasana yang nyaman sesuai dengan falsafah konstruktivisme. Pembelajaran kooperatif dapat meningkatkan kualitas proses belajar dan hasil belajar siswa. Hal tersebut dikemukakan Robert E. Slavin dalam Wina Sanjaya (2008), bahwa terdapat dua alasan yaitu: 1) Berdasarkan hasil beberapa penelitian yang dilakukan oleh pakar pendidikan membuktikan bahwa model pembelajaran kooperatif dapat meningkatkan prestasi belajar siswa sekaligus dapat meningkatkan kemampuan hubungan sosial, menumbuhkan sikap toleransi dan menghargai pendapat orang lain; 2) Model pembelajaran kooperatif secara teoritis dapat merealisasikan kebutuhan siswa dalam belajar berpikir kreatif, memecahkan masalah, dan mengintegrasikan pengetahuan dengan pengalaman.

Tujuan diadakannya PkM ini adalah untuk membantu meningkatkan kemampuan akademik siswa TK-SD kelas 3 (membaca, menghitung, dan menulis), dan siswa SD kelas 4-SMA (Matematika, IPA, dan Bahasa Inggris) melalui pendampingan belajar. Kegiatan ini bukan hanya untuk meningkatkan kemampuan akademik siswa melainkan juga menciptakan komunitas yang belajar berkesinambungan setelah pembelajaran dari sekolah. Kegiatan yang akan dilaksanakan adalah siswa belajar didampingi oleh tutor untuk SD kelas 4-SMA dan pendampingan siswa aktif dalam bentuk permainan dan aktivitas untuk TK-SD kelas 3 . Pembagian ini disesuaikan dengan karakteristik jenjang pendidikan siswa sebagai peserta didik dalam bimbingan belajar ini.

\section{METODE}

Berikut ini adalah metode pelaksanaan PkM bimbingan belajar di Curug Tangerang: 1) Ketua PkM merekrut mahasiswa calon guru yang akan mengajar (tutor) dan menunjuk diantaranya sebagai $\mathrm{PiC}$ tutor; 2) Ketua PkM mem-briefing seluruh tutor, mengenai tujuan kegiatan dan bagaimana pelaksanaannya; 3) Para tutor menyusun materi; 4) Ketua PkM dan PiC tutor membagi tutor untuk mengajar siswa TK, SD kelas 1-3, SD kelas 4-6, SMP, SMA; 5) Bimbingan belajar berlangsung; 6) Ketua PkM mengobservasi dan mendampingi para tutor setiap mengajar dan memberikan umpan balik; 7) Para tutor melakukan evaluasi pengajaran secara bersama setiap akhir kelas; 8) Para tutor meminta evaluasi kegiatan dari siswa dan orang tua untuk keseluruhan bimbingan belajar yang sudah terlaksana; 9) Saran, evaluasi, dan refleksi guru, refleksi orang tua, dan refleksi siswa, merupakan masukan untuk memperbaiki program bimbingan belajar yang akan dilaksanakan semester berikutnya.

\section{HASIL DAN PEMBAHASAN}

\section{Pelaksanaan PKM}

Berikut adalah skema pelaksanaan PkM yang telah dilaksanakan:

\begin{tabular}{|c|c|c|c|c|}
\hline No & Kegiatan & Tanggal & Tutor & Peserta \\
\hline 1. & Mengajar & 17 Sep 2019 & 6 & 14 \\
\hline 2. & Mengajar & 24 Sep 2019 & 6 & 15 \\
\hline 3. & Mengajar & 1 Okt 2019 & 9 & 16 \\
\hline 4. & Mengajar & 8 Okt 2019 & 9 & 19 \\
\hline 5. & Mengajar & 15 Okt 2019 & 9 & 20 \\
\hline 6. & Mengajar & 22 Okt 2019 & 9 & 17 \\
\hline 7. & Mengajar & 29 Okt 2019 & 9 & 18 \\
\hline 8. & Mengajar & $5 \quad$ Nov 2019 & 6 & 19 \\
\hline 9. & Mengajar & 12 Nov 2019 & 6 & 20 \\
\hline
\end{tabular}




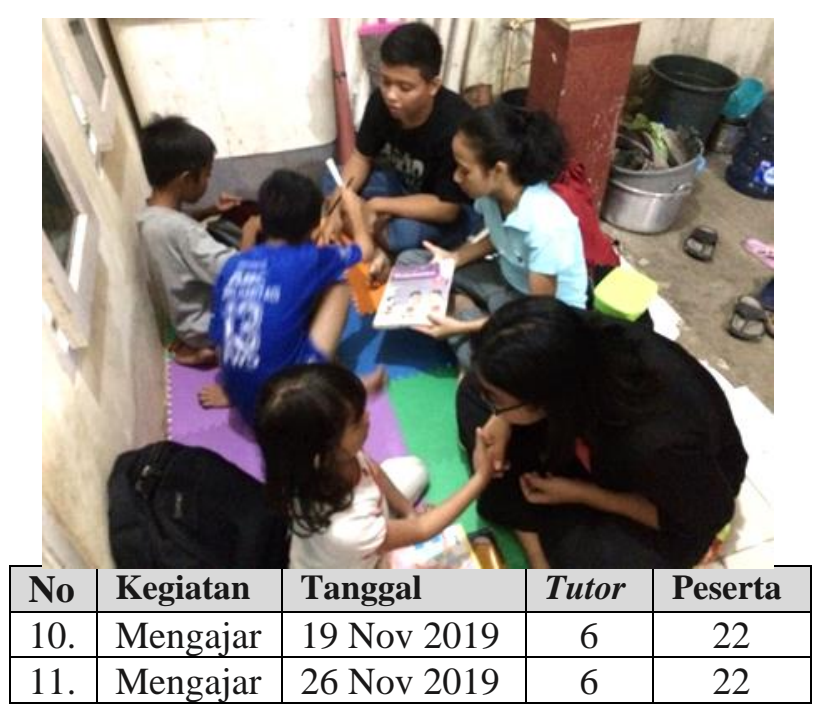

Gambar 3. Kegiatan Bimbingan Belajar 24 September 2019

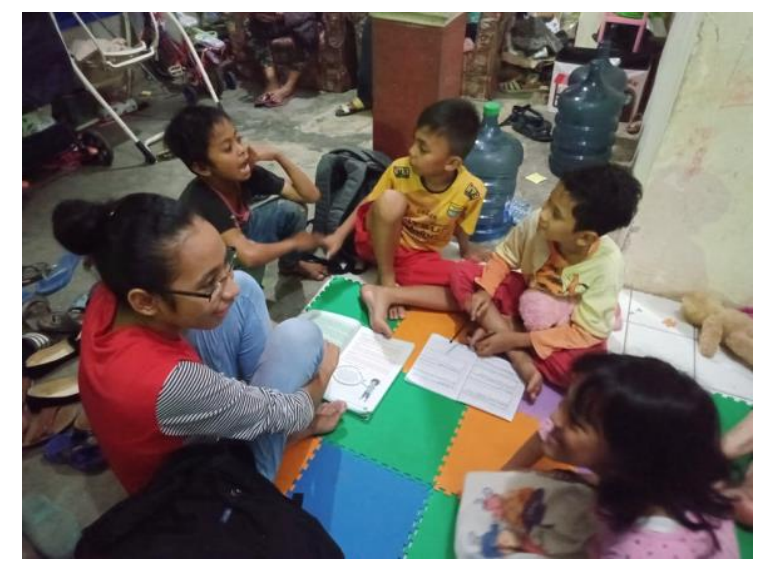

Gambar 4. Kegiatan Bimbingan Belajar 1 Oktober 2019

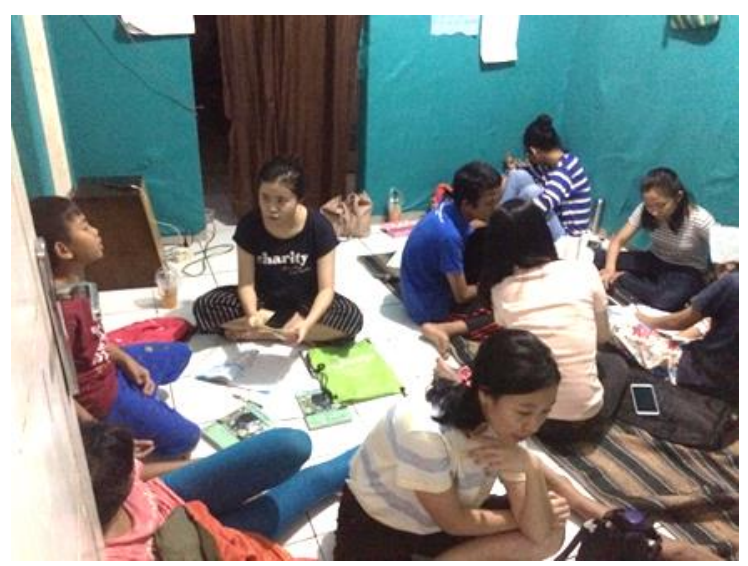

Gambar 5. Kegiatan Bimbingan Belajar 8 Oktober 2019
Gambar 6. Kegiatan Bimbingan Belajar 15 Oktober 2019

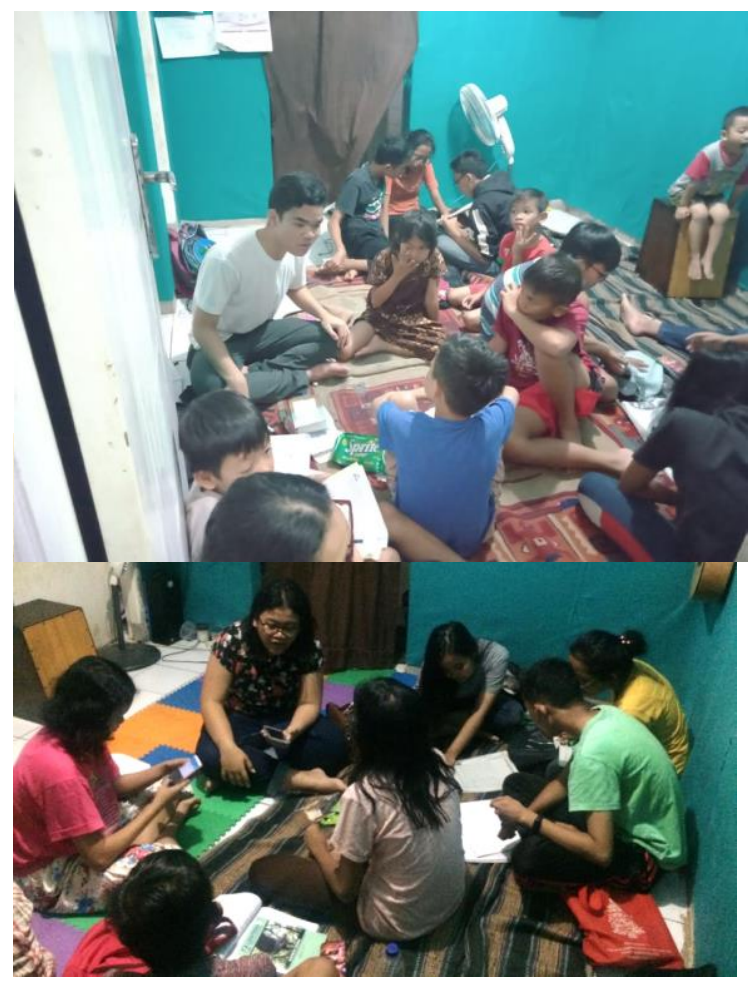

Gambar 5. Kegiatan Bimbingan Belajar 5 November 2019

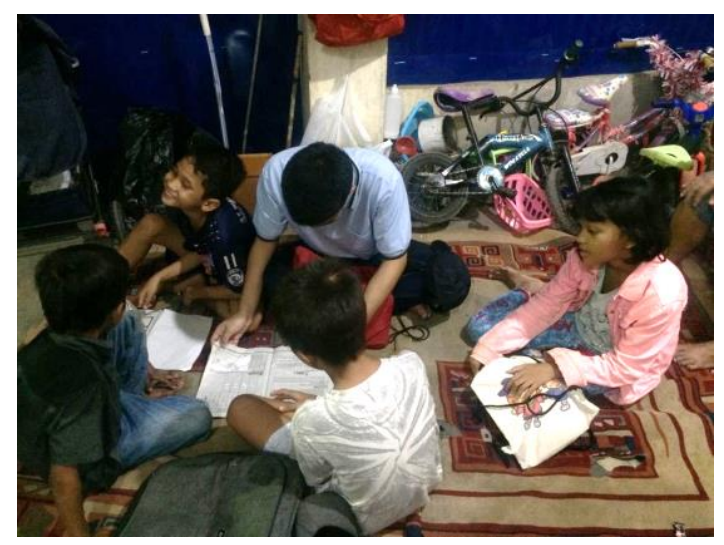

Gambar 6. Kegiatan Bimbingan Belajar 12 November 2019 
Pelaksanaan PKM ini diadakan sebanyak 11 kali pertemuan. Proses belajar mengajar dilakukan sekali dalam seminggu yaitu setiap hari Selasa. Diadakan mulai tanggal 17 September 2019 hingga 26 November 2019. Bekerja sama dengan Gereja Baptis Indonesia di daerah Perumahan Griya Karawaci, Curug. Bimbingan belajar dilaksanakan di di rumah salah seorang jemaat Gereja Baptis Indonesia di Perumahan Griya Karawaci. Kegiatan bimbingan belajar dilakukan pukul 18.00-20.00 WIB. Pemilihan waktu itu sesuai kesepakatan antara pihak orang tua siswa dan juga mahasiswa sebagai tutor.

\section{Hasil Kegiatan Bimbingan Belajar}

Kegiatan PkM Bimbingan belajar Eagle Nest yang bekerjasama dengan Gereja Baptis Indonesia mendapatkan sambutan yang sangat baik dari orang tua termasuk siswa-siswa yang dilayani. Hal ini disebabkan oleh hasil belajar siswa di sekolah yang mulai meningkat, (diutarakan oleh orang tua siswa). Dampak yang terlihat juga adalah adanya peningkatan jumlah siswa yang datang biasanya belasan siswa saja kemudian meningkat ke angka 20an siswa (lihat tabel pelaksanaan bimbingan belajar). Dampak lainnya juga adalah siswa mulai terbiasa belajar seusai persekolahan, tidak hanya itu siswa mendapatkan kehidupan sosial melalui bimbingan belajar ini. Mereka mendapatkan komunitas belajar dengan teman sejawat di lingkungan mereka tinggal.

Terdapat dampak positif dalam psikologis anak, khususnya dalam hal motivasi belajar. Orang tua bahkan tutor mengatakan bahwa ada anak yang awalnya malas-malasan, namun belakangan jauh lebih aktif, mau belajar, dan antusias bertanya kepada tutor saat bimbingan belajar berlangsung. Hal ini sejalan juga dengan laporan mingguan PiC Tutor bahwa siswa mulai tidak terlambat datang untuk ikut bimbingan belajar. Datang tepat waktu bahkan sering bertanya kepada tutor saat bimbingan bberlangsung. Setiap minggunya $\mathrm{PiC}$ tutor wajib melaporkan kepada dosen yang bertanggungjawab dalam bimbingan belajar ini termasuk mengirimkan fotofoto pelaksanaan bimbingan belajar.

Berdasarkan hasil yang baik dan juga respon dari orang tua siswa dan siswa, maka pelaksanaan PkM Bimbingan Belajar Eagle Nest ini akan dilanjutkan ke periode semester berikutnya, tentunya dengan mengevaluasi juga kekurangan untuk menjadi perbaikan semester berikutnya. Berdasarkan hasil evaluasi terdapat beberapa kekurangan dari PkM ini, dan diharapkan akan menjadi perbaikan untuk pelaksanaan kelanjutan dari bimbingan belajar ini, yaitu: 1) Diperlukannya meja belajar per orang karena anak-anak yang belajar kesulitan belajar dengan posisi belajar yang tidak nyaman; 2) Diperlukan ruangan yang lebih besar karena ruangan kecil dan banyaknya peserta yang mengikuti bimbingan belajar sehingga proses pembelajaran tidak kondusif; 3) Perlu dilakukan dua kali pertemuan setiap minggunya dan membagi anakanaknya menjadi dua kelompok, mengingat keterbatasan tempat yang sempit; 4) Diperlukan penambahan mahasiswa yang akan mengajar di bimbingan belajar Eagle Nest.

Beberapa saran dari orang tua siswa agar bimbingan belajar berikutnya dapat melaksanakan praktik sains atau bidang studi IPA. Nantinya praktik sains disesuaikan dengan topik yang dipelajari oleh siswa di sekolah. Tentunya ini adalah usul yang sangat baik, dan perlu diakomodasi oleh tutor, agar siswa mendapatkan pengetahuan yang lebih baik dengan melihat dan mengalami sendiri melalui praktik sains. Tidak dapat dipungkiri bahwa hal ini membutuhkan peralatan untuk melakukan praktek sederhana. Oleh karena itu masukan ini akan menjadi salah satu hal yang perlu diperhatikan dan masukan dalam pengajuan proposal untuk pengadaannya. Usulan ini selaras dengan yang dikatakan oleh Suryaningsih, (2017) bahwa metode praktikum adalah cara penyajian pelajaran dengan menggunakan metode percobaan. Dalam pelaksanaan metode ini siswa melakukan kegiatan yang mencakup pengendalian variabel, pengamatan, melibatkan pembanding atau kontrol, dan penggunaan alat-alat praktikum. Praktikum memegang peranan penting dalam pelajaran sains karena dapat memberikan latihan metode ilmiah kepada siswa. Rustaman, (2011) juga mengatakan hal yang sama bahwa dengan melakukan praktikum siswa juga akan lebih yakin akan satu hal dari pada hanya menerima dari guru dan buku, dapat memperkaya pengalaman, mengembangkan sikap ilmiah, dan hasil belajar akan bertahan lama dalam ingatan siswa. 
Hasil kegiatan bimbingan belajar pada tingkat SD adalah siswa dapat membaca dan menulis dengan benar. Pada tingkat SMP dan SMA difokuskan pada peningkatan kemampuan pelajaran matematika, IPA, dan bahasa Inggris. Berdasarkan umpan balik secara informal dari peserta bimbel dan pihak gereja menyatakan bahwa siswa sangat terbantu dengan adanya kegiatan belajar ini. PkM ini berlanjut ke semester berikutnya yaitu semester genap 2019/2020 dan tahun ajaran baru 2020/2021. Namun karena masa pandemik, dan tidak diperbolehkan kumpul apalagi dengan banyak orang dalam satu ruangan maka tidak memungkinkan lagi melakukan pembelajaran seperti dulu. Oleh karena itu bimbingan belajar dilakukan secara online. Tutor mengajar dari tempat asalnya dan bertemu secara virtual dengan siswa bimbingan belajar ini.

\section{KESIMPULAN}

Berdasarkan hasil kegiatan bimbingan belajar yang telah dilakukan, kesimpulan yang dapat diambil adalah kegiatan ini bermanfaat bagi siswa untuk meningkatkan kemampuan membaca, menulis, dan berhitung bagi siswa TK-SD dan juga meningkatkan kemampuan Matematika, IPA, dan Bahasa Inggris untuk siswa SMP-SMA.

Kegiatan ini disarankan untuk dilanjutkan pada semester mendatang dengan persiapan yang lebih baik dalam hal mempersiapkan tutor dan alat penilaian untuk mengukur ketercapaian manfaat terhadap siswa yang diajar. Selain itu, perlu dicakupkan manfaat kegiatan ini untuk mahasiswa guru dan juga sekaligus alat penilaian untuk mengukur ketercapaian tersebut. Fasilitas dan bahan pembelajaran untuk menunjang pembelajaran siswa harus diperhatikan. Ruangan untuk belajar siswa diharapkan dapat tercukupi. Juga dipersiapkan bukubuku penunjang untuk pembelajaran siswa.

\section{UCAPAN TERIMA KASIH}

Penulis hendak mengucapkan banyak terima kasih kepada:

1. Gereja Baptis Indonesia, yang sudah menginisiasi Bimbingan Belajar Eagle Nest yang berlangsung dan bertempat di Perumahan Griya Karawaci Curug dan memperkenalkan dengan dan memperkenalkan kepada UPH-Teachers College.

2. Mahasiswa Pendidikan Guru Sekolah Dasar (PGSD) Fakultas Ilmu Pendidikan Universitas Pelita Harapan sebagai tutor, yang sudah terlibat melayani dan mendidik siswa-siswi yang menjadi peserta Bimbingan Belajar ini.

3. LPPM UPH dari pimpinan dan staf, yang sudah sangat membantu memfasilitasi kegiatan pengabdian kepada masyarakat ini, dengan proposal PM-123-M/FIP/XI/2019.

Tanpa bantuan dan kerja sama ini, maka tidak mungkin Bimbingan Belajar Eagle Nest di Perumahan Griya Karawaci Curug dapat dilaksanakan. Terlebih lagi tidak mungkin ada manfaat yang dapat dirasakan oleh siswa-siswa peserta didik dari Bimbingan Belajar ini.

\section{REFERENSI}

Bakhtiyar. (2019). Peran Keluarga Sebagai Pendamping Belajar Anak Dalam Meraih Prestasi Belajar Di Sekolah Melalui Pelayanan Layanan Jasa Informasi Perpustakaan: Suatu Kajian Dalam Perspektif Sosio Kultural. Jurnal Perpustakaan Universitas Airlangga. Vol. 8.

Dwijayanti, G. \& Siswaningsih, W. (2004). Keterampilan Proses Siswa SMU Kelas II Pada Pembelajaran Kesetimbangan Kimia Melalui Metode Praktikum. Makalah.

Gagne, Robert, E.D. (1985). The cognitive Psychology of School Learning. Boston: Little, Brown \& Company.

Hill Dave. (1999). Social Class and Education: An Introduction to the Study of Education. David Fulton publishers.

Nurdyansyah \& Fahyuni, Eni. (2016). Inovasi Model Pembelajaran. Nizamia Learning Center Sidoarjo.

Qomaruddin (2017). Pentingnya Pendampingan Orang Tua Terhadap Pendidikan Anak. E-journal Kopertais. 
Rehalat, Aminah. (2014). Model Pembelajaran Pemrosesan Informasi. Jurnal Pendidikan Ilmu Sosial. Vol. 3.

Rohaeti, dkk. (2019). Program Pendampingan Berbasis Kearifan Lokal Desa, Adat Desa Senaru Dalam Meningkatkan Motivasi Belajar Anak-anak Desa Adat Senaru. Jurnal Pengabdian Kepada Masyarakat. Vol. 2.

Rustaman, N. (2005). Strategi Belajar Mengajar Biologi. Malang:UM Press.

Sanjaya, Wina. (2006). Pembelajaran Dalam Implementasi Kurikulum Berbasis Kompetensi. Jakarta: Prenada Media Group.

Santrock, John W. (2007). Psikologi Pendidikan. McGraw-Hill Company, Inc.

Slameto, Drs. (2010). Belajar Dan Faktorfaktor Yang Memengaruhinya. PT. Rineka Cipta Jakarta.

Subiantoro, A.W. (2005). Pentingnya Praktikum Dalam Pembelajaran IPA

Suryaningsih, Yeni. (2017). Pembelajaran Berbasis Praktikum Sebagai Sarana Siswa Untuk Berlatih Menerapkan Keterampilan Proses Sains Dalam Materi Biologi. Jurnal Pendidikan Biologi. Vol. 2.

Zaini, Ahmad dkk. (2015). Pengaruh StatusSosial Ekonomi Dan Tingkat Pendidikan Orang Tua Terhadap Minat Studi Lanjut Siswa Kelas XII Di Ma Miftahul Huda Cendono Purwosari Kabupaten Pasuruan. Jurnal Penelitian dan Pendidikan IPS (JPPI. Vol. 3. 